\title{
Comparative Analysis of the Use of Renewable Energy Sources in Selected Countries $^{4}$
}

\author{
Article history: \\ Received: 1 August 2018 \\ Sent for revision: 10 August 2018 \\ Received in revised form: 3 September 2018 \\ Accepted: 3 September 2018 \\ Available online: 2 October 2018
}

\begin{abstract}
The aim of the paper is to present the results of a comparative analysis of energy consumption from renewable sources in total energy consumption in four European countries - Italy, Norway, Ukraine and Serbia. The research is based on the analysis of scientific literature and secondary data sources. Based on a comprehensive literature review and analysis of statistical data from this area, the answer is obtained to the research question: what is the amount of the used renewable energy sources (RES) in selected European countries, which RES are used, in which sectors of the economy and what are the socio-economic effects of RES consumption. In addition, brief overviews of the framework and incentive measures that are applied in selected countries are presented in order to stimulate the use of renewable energy sources.
\end{abstract}

Keywords: Renewable energy sources, use of RES, regulation of RES, incentive measures, socio-economic effects.

\section{Komparativna analiza upotrebe obnovljivih izvora energije u odabranim zemljama}

Apstrakt: Cilj rada je da prikaže rezultate uporedne analize potrošnje energije iz obnovljivih izvora u ukupnoj potrošnji energije u četiri evropske zemlje -

\footnotetext{
${ }^{1}$ Economics Institute, Serbia, marija.reljic@ecinst.org.rs

2 University of Belgrade, Faculty of Organizational Sciences

${ }^{3}$ Economics Institute, Serbia

${ }^{4}$ This paper is a part of research project No. 179001 financed by the Ministry of

Education, Science and Technological Development of the Republic of Serbia
} 
Reljić M., et al: Comparative Analysis of the Use of Renewable Energy Sources in...

Italiji, Norveškoj, Ukrajini i Srbiji. Istraživanje je bazirano na analizi naučne literature i sekundarnih izvora podataka. Na osnovu sveobuhvatnog pregleda literature $i$ analize statističkih podataka iz ove oblasti, dolazi se do odgovora na istrazivačko pitanje: kolika je upotreba obnovljivih izvora energije (OIE) u izabranim evropskim zemljama, koji izvori OIE se koriste, u kojim sektorima privrede i koji su društveno-ekonomski efekti korišćenja OIE. Pored toga predstavljen je kratak pregled ragulatornog okvira i podsticajnih mera koje se primenjuju u odabranim zemaljama u cilju stimulisanja korišćenja obnovljivih izvora energije.

Ključne reči: Obnovljivi izvori energije, upotreba OIE, regulative OIE, mere podsticaja, društveno-ekonomski efekti.

\section{Introduction}

Inadequate energy production and the use of coal, oil and other nonrenewable derivatives is a problem that surpasses the national frameworks and is present at the global level. Traditional sources are irrationally consumed, slowly exhausted, and found in limited quantities. In addition, it should be noted that when used, these sources cause air pollution. In the last decade, progress has been made with regard to the use of RES from water, solar energy and wind energy, and the reduced energy intensity (Sustainable Development Goals - SDGs). However, this percentage is still small and RES is poorly used in the sectors of economy and everyday life of citizens.

In recent years, investments have been made for more rational use of energy, which are based on three basic principles: improvement of energy efficiency, conservation and savings in the use of energy, and the use of non-polluting and renewable energy sources. These principles have been actual in recent years, both globally and nationally. A number of conferences have been held and many of documents have been adopted concerning climate change, environmental protection and sustainable development. In this process, the developed countries are taking the lead, which are also the biggest polluters of our planet (Mihić et al, 2017). Accordingly, the United Nations implemented the Sustainable Development Strategy for the period from 2015 to 2030 or Agenda 2030, which replaced the Millennium Development Goals. The aim of the Strategy is to deal with the problems that have arisen on the world stage. Problems are presented through 17 Sustainable Development Goals (SDGs). Goals have the role of influencing decision-makers, both internationally and nationally, in order to enhance the lives of citizens and protect the nature we live in. More precisely, each of the UN member states should develop goals, sub-targets and indicators at the national level, and, on the other hand, countries should encourage each other through global partnerships. More 
Reljić M., et al: Comparative Analysis of the Use of Renewable Energy Sources in...

precisely, objectives 7 and 13 refer to sustainable energy sources and climate change. These goals tend to affect individuals by various measures and programs in order to save and conserve energy for "everyone". According to the 2030 climate and energy frameworks, the EU agreed to achieve a $40 \%$ reduction in greenhouse gas emissions (compared to 1990), 27\% of energy consumption from renewable sources and at least $27 \%$ of energy efficiency increase by 2030 (Agenda 2030, 2015).

\section{Renewable energy sources and economic development}

The topic of renewable energy sources (OEI) has become considerably popular among researchers and has been considered in several aspects (Andrei and others. 2017; Jorgenson and others2014; Devesaz and others, 2008; Chang et al., 2014). In the last decade, studies were conducted in order to show indicators that affect the production of energy in the world, in particular Europe (Andrei et al., 2017). A group of researchers emphasized the connection between energy and production processes (Chang et al., 2014), while a certain group of authors focused on the use of renewable sources in households (Hoefnagelsi et al., 2015).

According to a study conducted in Croatia, a certain group of social indicators, such as education and being informed, have been found to influence the use of renewable sources (Domac et al., 2004; Hornborg, 2008). Other researchers found that a significant number of countries continue to use nonrenewable energy sources in large quantities, primarily due to (lack of) information of their citizens. This is especially true for developing countries, where due to poor economic development, investments are not made in a better life of citizens (Romero et al, 2013). Similar opinion is shared by researchers who analysed the correlation between energy consumption and the performance of national economies (Esso et al, 2016). There is no doubt that the use of renewable energy also affects the economic growth of countries. A study carried out by a group of authors, focusing on $30 \mathrm{EU}$ countries, analysed the impact of nine economic variables on creating an energy paradigm. More precisely, the results confirmed that economic indicators have a significant impact on the development of public policies in the field of energy and on the achievement of sustainable economic development. This means, the more country is developed, the greater is the awareness of sustainable development (Popescu et al, 2018).

Modern economies have developed a specific energy standard depending on the consumption of conventional sources such as coal, gas or oil (Dusmanescu et al., 2014; Andrei et al., 2016). For example, EU countries have implemented incentive programs as early as 2000 to accelerate the use 
Reljić M., et al: Comparative Analysis of the Use of Renewable Energy Sources in...

of solar panels for the production of electricity in housing units, resulting in increased use of renewable resources at the national level (Romero et al, 2013). The share of RES in final energy consumption in the world reached $17.5 \%$ in 2015 (www.un.org).

Energy sector projects represent the basis of development in all countries. Energy innovation projects play an important role in the development of human society. These projects have the potential to create an environment that encourages the efficient use of energy potentials and faster economic growth. In addition, they are of great importance, as they can serve as an instrument of economic and political cooperation between countries (Mihić et al, 2015; Mihić et al, 2018).

Renewable energy is at the centre of transition to a less intensive and more sustainable energy system. RES developed rapidly in recent years, accompanied by a great reduction in costs of solar photovoltaic and wind energy. The International Energy Agency (IEA) expects electricity production from renewable sources to increase by more than one third by 2022 . However, the utilization of renewable sources for heating and transport is lagging behind, despite good potential (www.iea.org).

\section{Methodology and Results of Research}

The research is based on existing literature and secondary sources of data, collected from statistical reports. The analysis was carried out by reviewing the literature related to the use of RES published in international journals and international databases relevant to this field of research. Four European countries have been selected for research: Italy, Norway, Ukraine and Serbia. The selected countries include the EU member state (Italy), Norway as a politically and financially stable country, and two countries with the EU candidate status.

\subsection{Share of RES use in the total energy consumption of selected countries}

According to the latest official data, available on the website of the European Statistical Office, the production of electricity from renewable sources covers about $30 \%$ of gross consumption in the EU (28 countries). The most important renewable source in the EU is the energy of water, which according to the data for 2016, accounted for only $37 \%$ of gross electricity production. Next is wind energy with almost $32 \%$ and solar with less than $12 \%$. About a fifth of gross electricity production is covered by other renewable sources - biogas, geothermal energy and others. In the group of European countries, Norway is 
Reljić M., et al: Comparative Analysis of the Use of Renewable Energy Sources in...

the leader, which in 2016 covered $105 \%$ of electricity consumption with energy from renewable sources. In Serbia, $30 \%$ of the electricity consumed comes from renewable sources, while in Italy it is $34 \%$. The same data is not available for Ukraine.

According to data from the Energy Progress Report, within the observed countries, the largest consumer of energy from RES is Norway, with a share of $58 \%$. It is interesting to note that the next ranked country with $21 \%$ of the energy consumption from RES in total energy consumption is Serbia. Italy, which is also a EU member, records $17 \%$ of RES share in total energy consumption. Ukraine has a negligible share of RES in total energy consumption, only $4 \%$ (Figure 1 ).

Figure 1. Share of renewable energy in total electricity consumption (2015)

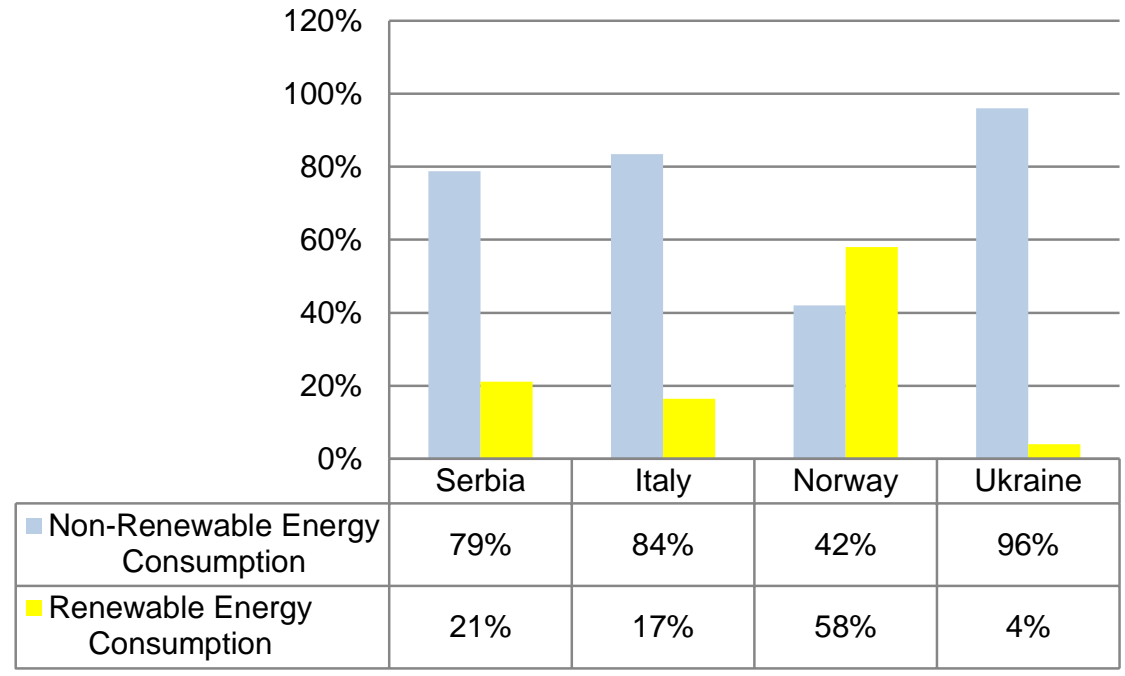

Source: The Energy Progress Report (TRACKING SDG7)

\subsection{The most commonly used RES in the selected countries}

The decision of one country regarding investment and the incentives in different renewable energy sources is mostly determined by their geographic location. Most importantly, a country has to identify its potentials that can be used in the most adequate way. Investment in wind power plants, solar power plants, geothermal power plants, biogas plants or small hydropower plants, therefore depends on the natural factors of the region. 
Reljić M., et al: Comparative Analysis of the Use of Renewable Energy Sources in...

According to the latest official data of the International Renewable Energy Agency, IRENA, $99.6 \%$ of Serbia's electricity production from renewable sources in 2016 is based on hydropower (Figure 2). Use of energy from other RES is negligible.

Figure 2. Trends in the production of electricity from renewable sources in the observed countries

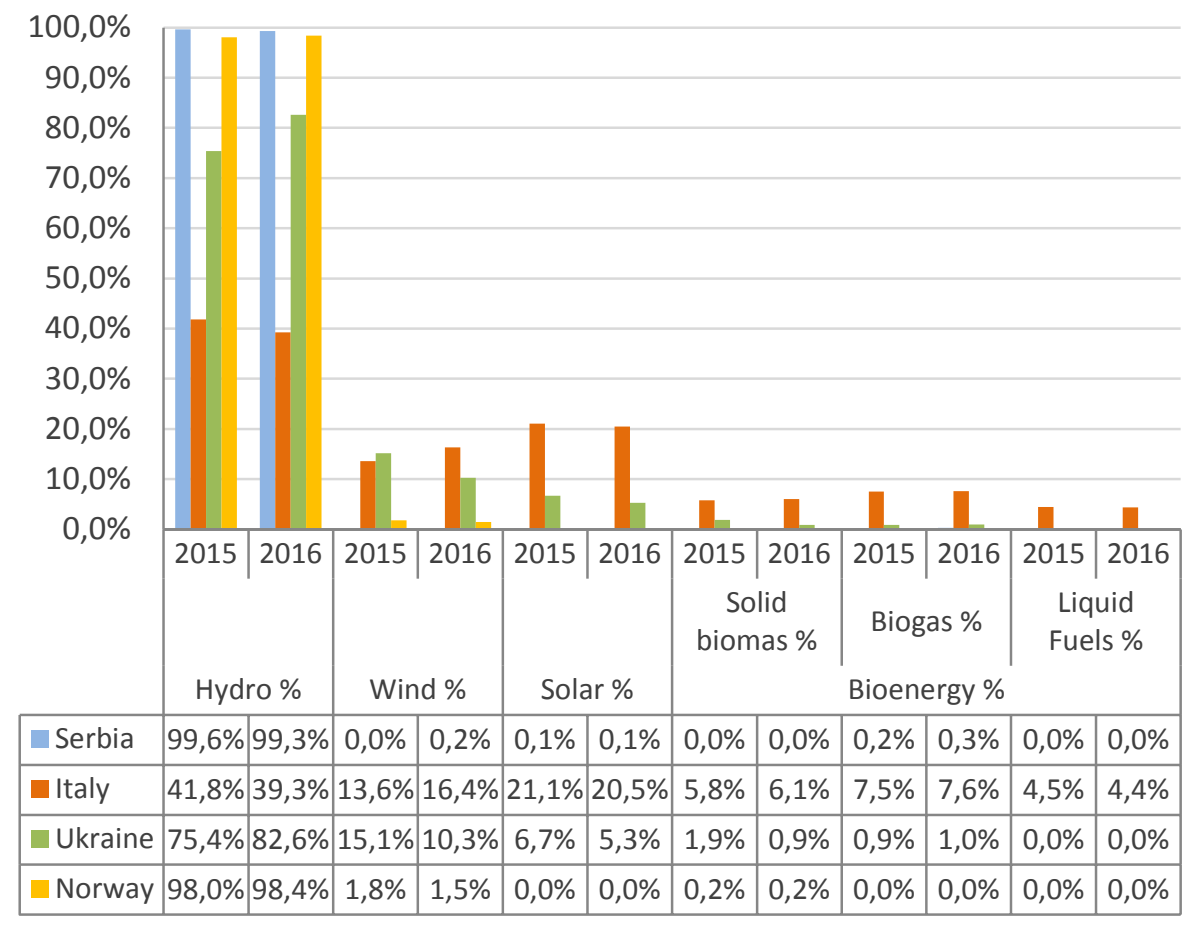

Source: IRENA

Furthermore, a high percentage of hydropower in the production of electricity from renewable sources is in Norway, where in 2015 and 2016, around 98\% of electricity was generated from water energy, while almost $2 \%$ was produced from wind energy. Other RES do not have significant participation.

As shown in Figure 2, in Ukraine, electricity from renewable sources is predominantly produced from hydropower $(75.4 \%$ in 2015 and $82.6 \%$ in 2016), while wind energy is present with a share of $15 \%$ in 2015 and $10 \%$ in 2016. Solar energy participates in the production of electricity with $6.7 \%$ and $5.3 \%$ in 2015 and 2016, respectively. 
Reljić M., et al: Comparative Analysis of the Use of Renewable Energy Sources in...

The situation in Italy is quite different. Hydroenergy represented $40 \%$ in the production of electricity from renewable sources in 2015 and 2016. The second most commonly used RES was solar energy with about $21 \%$ in the same period. Wind energy participated with $14 \%$ in 2015 and $16.4 \%$ in 2016 , while bioenergy (Biomass, biofuels and biogas) participated with $18 \%$ in both years.

From the above data, we can conclude that hydroelectric power was mostly used in the production of electricity from renewable sources in all selected countries. In Serbia and Norway, other sources are quite negligible. In Ukraine and Italy, the situation is different, and in addition to hydropower, the percentage of wind and solar energy used is also significant. In addition to these sources, the use of energy from biomass is very common in Italy.

\subsection{Sectors using RES}

The share of energy from RES used in industry, transport, commercial and residential facilities is different from country to country (Figure 3 ).

Figure 3. Sectors using energy from RES

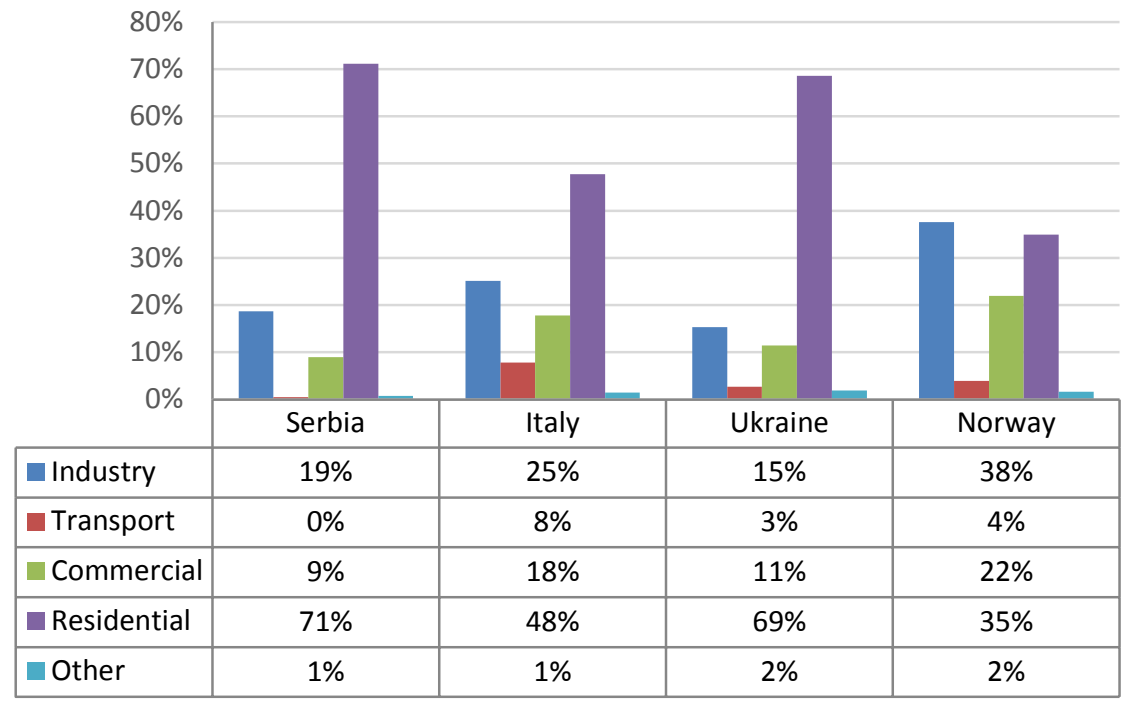

Note: data for Serbia are without Kosovo Source: IRENA

In Norway, the highest percentage of this energy $(38 \%)$ is used in the industrial sector, while in Serbia $(71 \%)$, Italy $(48 \%)$ and Ukraine $(69 \%)$ this 
Reljić M., et al: Comparative Analysis of the Use of Renewable Energy Sources in...

energy is mostly consumed in residential facilities. In addition to the industrial sector, in Norway, RES energy is still mostly used in residential (35\%) and commercial facilities (22\%). In these countries, with the exception of Norway, this energy, in addition to residential facilities, is mostly used for the industrial sector, in Italy $25 \%$, Serbia $19 \%$ and Ukraine 15\%. A significant percentage of energy from RES in these countries is still used in the commercial sector. What is important to note is that Serbia does not use RES in transportation at all. Unlike Serbia, all other countries have a significant share of the use of this energy in transport, Italy with a maximum of $8 \%$, followed by Norway with $4 \%$ and Ukraine with $3 \%$.

\section{Socio-economic effects}

Socio-economic analysis assesses the contribution of energy projects to the economic well-being of the entire country, region, local community. In considering the approach to the evaluation of investment projects in energy sector, which are very expensive, it should be noted that these projects bring effects to the whole society. Therefore, in the assessment of investment projects in energy sector, it is essential to take into account the comprehensive effects that these projects bring. Investment projects in energy sector are characterized by high costs of construction, a long period between the beginning of investment and the recovery of funds, and a high degree of economic risk (Mihić et al.,2017).

Numerous benefits can be achieved by improving energy efficiency and renewable energy, such as:

- Economic benefits - can ensure a stable price conditions and economic development. By improving energy efficiency, energy demand is decreasing, while increase in RES participation in energy production and consumption leads to secure supply, which additionally contributes to price stability. In addition, improving energy efficiency is cheaper than building new energy capacities.

- Stability of the energy system - promoting energy efficiency and reduced energy consumption can relieve the country's energy system, but only under the condition of increased participation of RES in total energy consumption, which ensures a long-term reduction in import dependency and enables that country to achieve energy stability.

- Benefits for the environment - reduction in energy consumption, caused by improving energy efficiency, leads to a reduction in the emission of harmful gases (Mihić et al., 2014). 
Reljić M., et al: Comparative Analysis of the Use of Renewable Energy Sources in...

Statistical data (Table 1) show significant differences between the values of exported and imported electricity in 2017 for each selected country. Italy is the second largest country in the world by the negative value of electricity exports, with the difference in the values of exported and imported electricity in 2017 amounting to 1.7 billion euros. Norway and Ukraine recorded positive values in electricity trade in 2017. They earned a profit worth 431 million euros (Norway) and 206.7 million euros (Ukraine). Serbia achieved a small negative difference in the trade of electricity of 3 million euros.

Table 1. Electricity trade (2017)

\begin{tabular}{|c|c|}
\hline Country & Trade value (euro) \\
\hline Norway & 431,3 million \\
\hline Ukraine & 206,7 million \\
\hline Serbia & -3 million \\
\hline Italy & $-1,7$ billion \\
\hline
\end{tabular}

Source: www.trademap.org

According to the IRENA - International Renewable Energy Agency, 9.8 million people worked in the sector of renewable energy sources, in 2016 worldwide. The EU employs 1.2 million people in this sector. RES sectors which employ the most people in the EU are wind energy (around 323,000) and solid biomass (around 333,000) in the EU (www.irena.org). Stable and predictable industrial and trade policies affect the growth of employment in the renewable sector around the world.

Figure 4. Number of employees in the RES sector (2016)

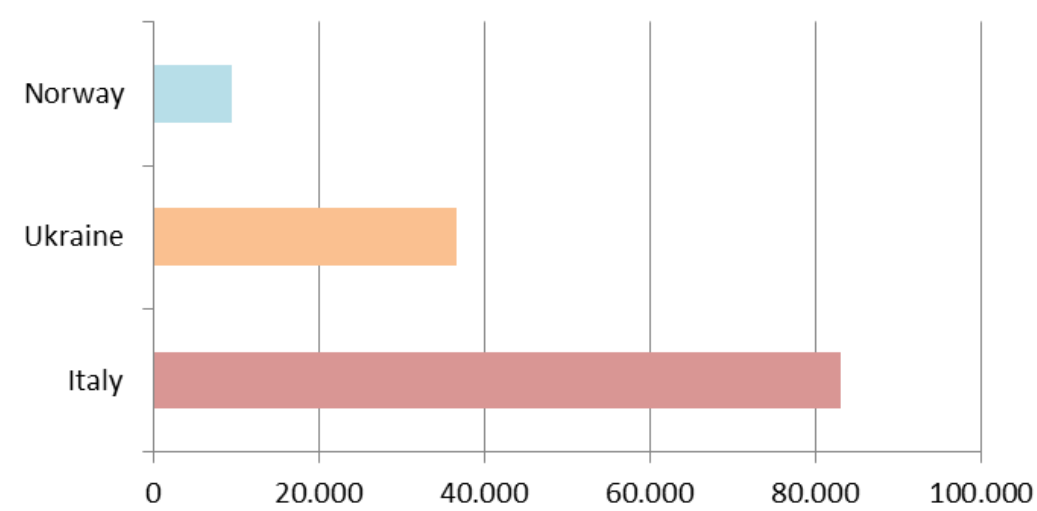

Source: IRENA 
Reljić M., et al: Comparative Analysis of the Use of Renewable Energy Sources in...

The figure 4 shows data on the number of jobs in the RES sector for selected countries without Serbia. For Serbia, there are no publicly available data related to this issue.

As the data show, the largest number of employees in the RES sector is in Italy, over 80,000 people. In Ukraine, there are a little less than 40,000 people in the sector, and about 10,000in Norway. This information is not available for Serbia.

The World Energy Council, in cooperation with Oliver Wyman, developed the Energy Trilemma Index, which serves to rank countries on the basis of their ability to provide sustainable energy. The three key elements of energy sustainability defined by the Council are: energy security, energy equity (accessibility and affordability) and environmental sustainability (Mihić et al, 2018). Ranking by the index measures the overall performance in achieving a sustainable mix of policies, while the balance score highlights how well a country makes a compromise between Energy security, Energy equity, and Environmental sustainability. Table 2 shows data for 2017 for selected countries according to the Energy Trilemma Index.

Table 2. Country's ability to provide sustainable energy to the Energy Trilemma Index (2017)

\begin{tabular}{|l|l|l|l|c|c|c|c|}
\hline $\begin{array}{l}\text { Index } \\
\text { rank }\end{array}$ & Country & $\begin{array}{l}\text { Balance } \\
\text { score }\end{array}$ & $\begin{array}{l}\text { Energy } \\
\text { security }\end{array}$ & $\begin{array}{l}\text { Energy } \\
\text { equity }\end{array}$ & \multicolumn{3}{|l|}{$\begin{array}{l}\text { Environmental } \\
\text { sustainability }\end{array}$} \\
\hline 7. & Norway & BAA & 32 & 23 & \multicolumn{3}{|c|}{8} \\
\hline 16. & & Italy & AAA & 17 & 35 & 13 \\
\hline 48. & & Ukraine & ABD & 11 & 63 & 102 \\
\hline 68. & Serbia & BBC & 51 & 70 & 88 \\
\hline
\end{tabular}

Source: https://trilemma.worldenergy.org/

If we consider Serbia and Italy, it is noticeable that there is energy dependence, especially in the case of Italy, which in 2017 was heavily dependent on electricity imports. One of the possibilities for reducing energy dependence is precisely the greater use of RES from its own sources in the production of electricity. Another possibility is the application of energy efficiency as a measure to reduce irrational power consumption. It is inevitable that as time goes by, individual countries will depend on the import of electricity, because coal supplies are consumed on a daily basis. Therefore, the task of each country, and mostly those that are already dependent on electricity imports, is to actively engage in investing in RES.

Given the parameters of environmental sustainability, i.e. supply and demand for energy efficiency, as well as energy supply from renewable sources and other sources of low carbon dioxide emissions, Norway is in 8th, Italy in $13^{\text {th }}$ 
Reljić M., et al: Comparative Analysis of the Use of Renewable Energy Sources in...

place, followed by Serbia in 88th and Ukraine in 102th place out of 125 countries.

IRENA - International Renewable Energy Agency published the report RENEWABLE ENERGY BENEFITS: MEASURING THE ECONOMICS, which shows the first quantification of the macroeconomic effects of doubling the global share of renewable energy in total energy mix by 2030. In order to achieve the objectives set by Paris agreement and Sustainable Development Goals, transition to sustainable energy is crucial to meeting these goals. Policy makers within the RES are considering the best policies while taking into account socioeconomic benefits of this transition. The report shows that by doubling the share of RES in the global energy mix by 2030, GDP will grow in 2030 between $0.6 \%$ and $1.1 \%$, which is equivalent to 700 billion or 1.3 trillion USD. Most of these positive effects on GDP are conditioned by higher investments in RES, which leads to the ripple effect throughout the economy. Although, benefits from RES when it comes to welfare can not be measured precisely in the traditional way, report shows that doubling the share of RES by 2030 would have a positive impact on the global welfare of people, which would increase by $2.7 \%$. If a higher rate of electrification of heating and transport would be achieved, the global welfare rate would increase by $3.7 \%$ (www.cire.pl).

Doubling the share of RES, increases employment to 20.4 million by 2030 . Taking into account all the above, we can say that policy makers have the chance to use benefits of this transition to sustainable energy and make the best for their national economies. Doubling the share of RES in global energy has a positive impact in terms of economic growth, social protection, job creation and overall trade balance. Benefits depend on a set of factors that include a diversified economy and sufficient market capacity to absorb opportunities for job creation, including training and education that help build a skilled and versatile staff (www.cire.pl). Economic growth also depends on increasing investment in RES expansion without reducing investment in other sectors. It is therefore important to say that many potential benefits of the accelerated RES development depend on sufficient financial resources.

\section{Overview of the regulatory framework and incentives}

Depending on several factors, among which the most dominant are political and financial stability of the country, different results are achieved regarding the use of RES. Investments in renewable energy sources are best fostered by the application of well-defined policies that create robust and transparent regulatory frameworks, provide various incentives for investments and set long-term goals for the production of renewable energy. The planning of such 
Reljić M., et al: Comparative Analysis of the Use of Renewable Energy Sources in...

a regulatory framework is the responsibility of the government, which defines the main objectives, key policies and introduces the necessary technical, regulatory and financial regulations.

In Italy there are a large number of documents concerning the RES sector. Some of the most important are the Budget Law 2007 - Energy Efficiency provisions, Italy National Energy Strategy 2017, National Strategy for GHG emissions, Action Plan for the environmental sustainability of consumption of public administration, the National Renewable Energy Action Plan (NREAP), the National Energy Strategy 2017 and National System of sustainability certification for Biofuels. In addition to these, there are a number of regulations, promotions, incentives for promoting different types of RES such as: Increasing Energy Efficiency Support Scheme (Conto Termico 2.0), Storage Systems, Decree on the Cutting of Incentives for Photovoltaics (Spalma Incentives), Promotion of High Efficiency Cogeneration, National Electric System Research, Action Plan for the environmental sustainability of consumption of public administration, Feed-In Tariff for Solar Thermodynamic Energy, Simplified Purchase and Resale Arrangements, Reorganisation of Energy Sector Regulation (www.iea.org).

The renewable energy sector in Norway is defined by the following important laws: Act on Offshore Renewable Energy Production, National Strategy for Research, Development, Demonstration and Commercialisation of New Energy Technology (Energi21), Strategy for Small-scale Hydropower, National Renewable Energy Action Plan (NREAP). In addition to these regulations, there is a large number of investment assistance related to different types of innovative energy and climate technologies. There are programs and support for the production of RES. Some of them are: Investment aid for Energy measures in households through Enova SF, ENERGIX Programme, Investment aid and conditional loans to innovative energy and climate technology through Enova SF, Centres for Environmentally-friendly Energy Research, Environmental Technology Scheme, Investment aid to promote innovative energy systems and renewable district heating and cooling through Enova SF, Investment aid and conditional loans to support development and deployment of energy and climate efficient technologies and measures through Enova SF. In this country, a tax on oil, waste disposal, electricity and $\mathrm{CO} 2$ has been introduced as an incentive to use RES (www.iea.org ).

The production and distribution of electricity in Ukraine is regulated by the Ukraine's Electricity Market Law (Law no 4493), Law on Alternative Energy Sources, Law on Promotion of Biological Fuels Production and Use (No. 1391-VI), Law on Energy Savings, Law on Alternative Liquid and Gaseous Fuels and other laws and regulatory acts issued by the Cabinet of Ministers of Ukraine. The National Renewable Energy Action Plan (NREAP) is, as with 
Reljić M., et al: Comparative Analysis of the Use of Renewable Energy Sources in...

other countries, an integral part of the regulation. Ukraine introduced in its regulatory system following measures of incentives: Corporate income tax exemptions in Ukraine available for renewable energy sector, Green Tariff (Feed-in Tariff), VAT and Customs Duties Exemptions and Programme for State Support of Non-traditional and Renewable Energy Sources (www.iea.org).

The key acts on the basis of which the Republic of Serbia regulates the production of electricity from renewable sources is the Energy Law, with accompanying regulatory documents, and the Energy Sector Development Strategy of the Republic of Serbia for the period by 2025 with projections by 2030. In addition to these two documents, the 2013 National Renewable Energy Action Plan (NREAP) aims to stimulate investments in this area. The legal framework with incentive tariffs was introduced in the Republic of Serbia for the first time in 2009 (www.iea.org).

Energy policy has been elaborated and applied within the framework of the Energy Sector Development Strategy of the Republic of Serbia, the Strategy Implementation Program and the Energy Balance of the Republic of Serbia. (www.energetskiportal.rs). In accordance with the Strategy and Program, the Government adopts national action plans, which define in more detail the development goals and measures for their implementation.

Table 3. Documents that represent key elements of the renewable energy policy framework

\begin{tabular}{|c|c|c|c|}
\hline Title & Year & Policy Type & Policy Target \\
\hline \multicolumn{4}{|c|}{ ITALY } \\
\hline $\begin{array}{l}\text { Ministerial Decree on } \\
\text { the promotion of } \\
\text { biomethane and } \\
\text { advanced biofuels in } \\
\text { transport for the period } \\
2018-2022 \\
\end{array}$ & 2018 & $\begin{array}{ll}\text { Policy } & \text { Support>Strategic } \\
\text { planning } & \end{array}$ & $\begin{array}{l}\text { Bioenergy>Biofuels for } \\
\text { transport }\end{array}$ \\
\hline $\begin{array}{l}\text { Italy National Energy } \\
\text { Strategy } 2017\end{array}$ & 2017 & $\begin{array}{ll}\text { Policy } & \text { Support>Strategic } \\
\text { planning } & \end{array}$ & $\begin{array}{ll}\text { Multiple } & \text { RE } \\
\text { Sources }>\text { All } & \end{array}$ \\
\hline $\begin{array}{ll}\text { National } & \text { Energy } \\
\text { Strategy } & \\
\end{array}$ & 2013 & $\begin{array}{l}\text { Regulatory Instruments, Policy } \\
\text { Support>Strategic planning }\end{array}$ & Multiple RE Sources \\
\hline $\begin{array}{l}\text { National } \text { Renewable } \\
\text { Energy } \text { Action Plan } \\
\text { (NREAP) }\end{array}$ & 2010 & $\begin{array}{ll}\text { Policy } & \text { Support>Strategic } \\
\text { planning } & \end{array}$ & $\begin{array}{lr}\text { Multiple RE Sources, } \\
\text { Multiple } & \text { RE } \\
\text { Sources>All, Multiple } \\
\text { RE Sources>Cooling, } \\
\text { Multiple } \\
\begin{array}{l}\text { Sources>Heating, } \\
\text { Multiple } \\
\text { Sources>Power }\end{array} \\
\end{array}$ \\
\hline Emission & 2006 & $\begin{array}{l}\text { Policy Support, } \quad \text { Economic } \\
\text { Instruments }>\text { Market-based } \\
\text { instruments }>\text { GHG emissions } \\
\text { trading }\end{array}$ & $\begin{array}{l}\text { Bioenergy >Biofuels for } \\
\text { transport }\end{array}$ \\
\hline
\end{tabular}


Reljić M., et al: Comparative Analysis of the Use of Renewable Energy Sources in...

\begin{tabular}{|c|c|c|c|}
\hline Title & Year & Policy Type & Policy Target \\
\hline $\begin{array}{lr}\text { Reorganisation } & \text { of } \\
\text { Energy } & \text { Sector } \\
\text { Regulation } & \end{array}$ & 2004 & $\begin{array}{l}\text { Economic Instruments }>\text { Market- } \\
\text { based instruments>Green } \\
\text { certificates, Policy } \\
\text { Support>Strategic planning, } \\
\text { Regulatory Instruments>Other } \\
\text { mandatory requirements, } \\
\text { Regulatory Instruments }\end{array}$ & $\begin{array}{l}\text { Multiple } \\
\text { Sources>Power, } \\
\text { Multiple RE } \\
\text { Sources }>\text { CHP, Multiple } \\
\text { RE Sources>Heating }\end{array}$ \\
\hline \begin{tabular}{lr}
\multicolumn{3}{l}{ Fund for } & Greenhouse \\
Gas & Emissions \\
Reduction, & Energy \\
Efficiency & and \\
\multicolumn{2}{l}{ Sustainable Energy }
\end{tabular} & 2001 & $\begin{array}{l}\text { Policy } \quad \text { Support }>\text { Institutional } \\
\text { creation, } \\
\text { Instruments }>\text { Fiscal/financial } \\
\text { incentives }>\text { Taxes }\end{array}$ & Multiple RE Sources \\
\hline $\begin{array}{l}\text { Utility targets for } \\
\text { increasing } \quad \text { energy } \\
\text { efficiency }\end{array}$ & 2001 & $\begin{array}{l}\text { Economic Instruments }>\text { Market- } \\
\text { based instruments }>\text { GHG } \\
\text { emissions trading, Economic } \\
\text { Instruments>Fiscal/financial } \\
\text { incentives }>\text { Tax relief, Policy } \\
\text { Support, Policy } \\
\text { Support>Strategic planning, } \\
\text { Regulatory Instruments>Other } \\
\text { mandatory requirements }\end{array}$ & $\begin{array}{l}\text { Multiple RE } \\
\text { Sources>Power, } \\
\text { Bioenergy>Biomass for } \\
\text { heat, } \\
\text { Bioenergy>Biomass for } \\
\text { power, } \\
\text { Geothermal>Power, } \\
\text { Multiple RE } \\
\text { Sources>CHP, Multiple } \\
\text { RE Sources>Heating }\end{array}$ \\
\hline $\begin{array}{l}\text { National Strategy for } \\
\underline{\text { GHG emissions }}\end{array}$ & 1999 & $\begin{array}{l}\text { Policy Support>Strategic } \\
\text { planning, } \\
\text { Instruments>Direct } \\
\text { investment>Funds to sub- } \\
\text { national governments, } \\
\text { Economic } \\
\text { Instruments>Fiscal/financial } \\
\text { incentives>Loans }\end{array}$ & Multiple RE Sources \\
\hline $\begin{array}{lr}\text { Distribution } & \text { of } \\
\text { competencies } \quad \text { for } \\
\text { energy between State } \\
\text { and Regions }\end{array}$ & 1998 & $\begin{array}{ll}\text { Policy } & \text { Support>Strategic } \\
\text { planning } & \end{array}$ & Multiple RE Sources \\
\hline $\begin{array}{l}\text { Measures to promote } \\
\begin{array}{lr}\text { distributed } & \text { generation } \\
\text { and } & \text { market } \\
\text { liberalisation }\end{array} \\
\end{array}$ & 1991 & $\begin{array}{ll}\text { Policy } & \text { Support }>\text { Strategic } \\
\text { planning } & \end{array}$ & $\begin{array}{l}\text { Multiple } \\
\text { Sources>All }\end{array}$ \\
\hline \multicolumn{4}{|c|}{ NORWAY } \\
\hline $\begin{array}{l}\text { Investment aid for } \\
\text { Energy measures in } \\
\text { households though } \\
\text { Enova SF }\end{array}$ & 2013 & $\begin{array}{l}\text { Economic } \\
\text { Instruments>Fiscal/financial } \\
\text { incentives }\end{array}$ & $\begin{array}{ll}\text { Multiple } & \mathrm{RE} \\
\text { Sources>Heating, } \\
\text { Multiple } \\
\text { Sources>Power, } \\
\text { Multiple RE Sources } \\
\end{array}$ \\
\hline $\begin{array}{l}\text { Norway-Sweden } \\
\text { Green Certificate } \\
\text { Scheme for electricity } \\
\text { production }\end{array}$ & 2012 & $\begin{array}{l}\text { Policy Support, Economic } \\
\text { Instruments }>\text { Market-based } \\
\text { instruments }>\text { Green certificates }\end{array}$ & $\begin{array}{l}\text { Multiple RE } \\
\text { Sources>Power, } \\
\text { Multiple RE Sources }\end{array}$ \\
\hline $\begin{array}{l}\text { National } \text { Renewable } \\
\text { Energy Action Plan } \\
\text { (NREAP) } \\
\end{array}$ & 2012 & Support>Strategic & Multiple RE Sources \\
\hline $\begin{array}{lr}\text { Act } \quad \text { on } & \text { Offshore } \\
\text { Renewable } & \text { Energy } \\
\end{array}$ & 2010 & $\begin{array}{l}\text { Regulatory } \\
\text { Instruments>Monitoring, Policy }\end{array}$ & $\begin{array}{l}\text { Wind }>\text { Offshore, } \\
\text { Ocean, Ocean>Other, }\end{array}$ \\
\hline
\end{tabular}


Reljić M., et al: Comparative Analysis of the Use of Renewable Energy Sources in...

\begin{tabular}{|c|c|c|c|}
\hline Title & Year & Policy Type & Policy Target \\
\hline Production & & 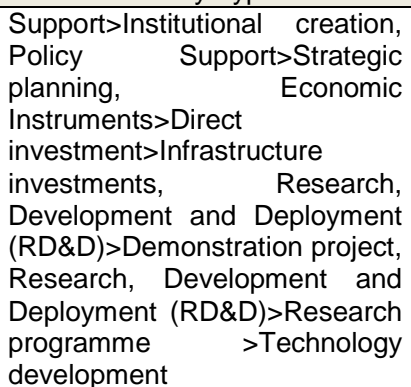 & $\begin{array}{l}\text { Ocean }>\text { Tidal, } \\
\text { Ocean }>\text { Wave }\end{array}$ \\
\hline $\begin{array}{l}\text { National Strategy for } \\
\text { Research, } \\
\text { Development, } \\
\text { Demonstration and } \\
\text { Commercialisation of } \\
\text { New Energy } \\
\text { Technology (Energi21) }\end{array}$ & 2008 & $\begin{array}{l}\text { Policy Support, Policy } \\
\text { Support>Strategic planning, } \\
\text { Research, Development and } \\
\text { Deployment (RD\&D) }\end{array}$ & $\begin{array}{lr}\text { Multiple RE } & \text { Sources, } \\
\text { Multiple } & \text { RE } \\
\text { Sources>All } & \end{array}$ \\
\hline $\begin{array}{ll}\text { White Paper on } \\
\text { Innovative Activity for } \\
\text { Environmentally } \\
\text { Friendly } \\
\text { Technologies }\end{array}$ & 2004 & Policy Support & $\begin{array}{ll}\text { Multiple } & R E \\
\text { Sources>Power }\end{array}$ \\
\hline $\begin{array}{l}\text { White Paper on } \\
\text { Energy Supply }\end{array}$ & 2003 & Policy Support & $\begin{array}{ll}\text { Multiple } & R E \\
\text { Sources }>\text { Power } & \end{array}$ \\
\hline $\begin{array}{l}\text { Investment aid to } \\
\text { promote innovative } \\
\text { energy systems and } \\
\text { renewable district } \\
\text { heating and cooling } \\
\text { though Enova SF }\end{array}$ & 2003 & $\begin{array}{l}\text { Economic Instruments>Direct } \\
\text { investment>Infrastructure } \\
\text { investments, } \quad \text { Economic } \\
\text { Instruments>Fiscal/financial } \\
\text { incentives }>\text { Grants } \quad \text { and } \\
\text { subsidies, } \\
\text { Support>Institutional creation, } \\
\text { Policy Support>Strategic } \\
\text { planning }\end{array}$ & $\begin{array}{ll}\text { Multiple } & R E \\
\text { Sources }>\text { Heating } & \end{array}$ \\
\hline $\begin{array}{l}\text { Information and advice } \\
\text { on energy efficiency } \\
\text { and renewable energy } \\
\text { though Enova SF } \\
\end{array}$ & 2002 & $\begin{array}{ll}\text { Policy } & \text { Support>Institutional } \\
\text { creation, Information and } \\
\text { Education }\end{array}$ & $\begin{array}{l}\text { Multiple } \\
\text { Sources }>\text { All }\end{array}$ \\
\hline \multicolumn{4}{|c|}{ UKRAINE } \\
\hline$\frac{\text { National Renewable }}{\frac{\text { Energy Action Plan }}{\text { (NREAP) }}}$ & $\begin{array}{l}2014 \text { (Oct } \\
1 \mathrm{st})\end{array}$ & $\begin{array}{l}\text { Policy Support }>\text { Strategic } \\
\text { planning, Economic } \\
\text { Instruments }>\text { Fiscal/financial } \\
\text { incentives }>\text { Tax relief }\end{array}$ & $\begin{array}{l}\text { Multiple RE Sources, } \\
\text { Multiple RE } \\
\text { Sources }>\text { All }\end{array}$ \\
\hline $\begin{array}{l}\frac{\text { Law on Promotion of }}{\text { Biological Fuels }} \\
\frac{\text { Production and Use }}{(\text { No. 1391-VI) }}\end{array}$ & $\begin{array}{l}2009 \text { (Mai } \\
21 \text { st) }\end{array}$ & $\begin{array}{l}\text { Regulatory Instruments, Policy } \\
\text { Support }\end{array}$ & $\begin{array}{c}\text { Bioenergy>Biofuels for } \\
\text { transport }\end{array}$ \\
\hline$\frac{\frac{\text { Law on Combined }}{\text { Heat and Power }}}{\frac{\text { (cogeneration) and }}{\text { Waste Energy }}}$ & 2005 & $\begin{array}{l}\text { Policy Support, Regulatory } \\
\text { Instruments }\end{array}$ & $\begin{array}{c}\text { Multiple RE } \\
\text { Sources }>\text { CHP }\end{array}$ \\
\hline
\end{tabular}

Industrija, Vol.46, No.3, 2018 
Reljić M., et al: Comparative Analysis of the Use of Renewable Energy Sources in...

\begin{tabular}{|c|c|c|c|}
\hline Title & Year & Policy Type & Policy Target \\
\hline$\frac{\text { Law on Alternative }}{\text { Energy Sources }}$ & 2003 & $\begin{array}{c}\text { Policy Support>Strategic } \\
\text { planning } \\
\end{array}$ & Multiple RE Sources \\
\hline $\begin{array}{l}\frac{\text { Law on Alternative }}{\text { Liquid and Gaseous }} \\
\underline{\text { Fuels }}\end{array}$ & $\begin{array}{l}2000 \text { (last } \\
\text { amended } \\
2012)\end{array}$ & $\begin{array}{l}\text { Policy Support>Strategic } \\
\text { planning, Policy Support }\end{array}$ & $\begin{array}{c}\text { Bioenergy }>\text { Biofuels for } \\
\text { transport }\end{array}$ \\
\hline$\frac{\text { Law on Energy }}{\underline{\text { Savings }}}$ & 1994 & $\begin{array}{c}\text { Policy Support>Strategic } \\
\text { planning, Policy Support, } \\
\text { Research, Development and } \\
\text { Deployment (RD\&D) }\end{array}$ & $\begin{array}{l}\text { Multiple RE Sources, } \\
\text { Multiple RE } \\
\text { Sources>All }\end{array}$ \\
\hline \multicolumn{4}{|c|}{ SERBIA } \\
\hline $\begin{array}{l}\text { National Renewable } \\
\text { Energy Action Plan } \\
\text { (NREAP) }\end{array}$ & $\begin{array}{l}2013 \\
\text { (June } \\
\text { 28th) }\end{array}$ & $\begin{array}{ll}\text { Policy } & \text { Support }>\text { Strategic } \\
\text { planning } & \end{array}$ & Multiple RE Sources \\
\hline Energy law & $\begin{array}{l}2011 \text { (last } \\
\text { amended } \\
\text { 2012) }\end{array}$ & Support>Strategic & $\begin{array}{lr}\text { Multiple RE Sources, } \\
\text { Multiple } \\
\text { Sources>All, Multiple } \\
\text { RE Sources }>\text { Cooling, } \\
\text { Multiple RE } \\
\text { Sources>Heating, } \\
\text { Multiple } \\
\text { Sources>Power }\end{array}$ \\
\hline
\end{tabular}

Source: International Energy Agency (IEA),

(https://www.iea.org/policiesandmeasures/renewableenergy/?country=\&country)

From Table 3 we can see that Italy and Norway have the most official legal documents relating to RES. In addition, they have the most strategic documents and plans related to direct support to the development of the RES sector. Ukraine also has several laws that apply to this sector, but fewer incentives for RES. In Serbia, the situation is a bit different, and there is only one law that relates to the RES sector, and a small number of incentives for this sector. Only Italy adopted the regulations that came into force last year, while all other countries adopted laws a few years ago.

All the countries mentioned above signed the National Renewable Energy Action Plan (NREAP). By signing this agreement, countries are committed to implementing different directives in the field of renewable energy sources, and in accordance with Directive 2009/28/E3 they adopted binding targets for EU member states which are to ensure that RES by 2020 participate with $20 \%$ in the gross final consumption at EU level; as well as to improve energy efficiency in the same period by $20 \%$ (www.energetskiportal.rs). The Annexes specify the individual objectives of each Member State. Directive 2009/28/EC is of utmost importance for the promotion of the use of renewable energy sources and the reduction of energy production from sources leading to alarming pollution. The directive points to high importance of using renewable energy sources and the serious approach to this topic in the European Union. 
Reljić M., et al: Comparative Analysis of the Use of Renewable Energy Sources in...

\section{Conclusion}

All the data in this paper show that it is necessary to change the approach to the use of renewable energy. Reserves of traditional energy derivatives are being spent every day and are being slowly exhausted. Developing awareness of the protection of the planet against pollution has been in focus for many years. The use of RES has become a prerequisite for the development of the economy of each country, irrelevant to the geographical location.

From the paper we can conclude that within the observed countries, Norway is the largest RES consumer with a share of $58 \%$. It is interesting that Serbia, a developing country, occupies the second place, unlike Italy, which is a EU member state and participates with a smaller share of RES consumption.

Electricity from RES in all selected countries is mostly generated from hydro energy. Although in Norway and Serbia it is almost the only way of producing energy from RES, in Ukraine and Italy the energy of the wind and the sun is also used. Furthermore, Italy uses biomass energy.

Renewable energy, in all observed countries, is most widely used in the industrial sector and residential facilities. It is important to conclude that all countries except Serbia use RES in transport in some percentage.

Numerous socioeconomic advantages are achieved by using energy from renewable sources. This is reflected in price stability, energy sector stability, environmental benefits, and employment growth. The paper states that the largest number of employees in the RES sector is in Italy $(80,000)$. It is assumed that the number of employees in Serbia in this sector is negligible, compared to the total number of employees in the energy sector. According to the data that were processed in the paper, it is noticeable that in contrast to Norway and Ukraine, Serbia and especially Italy, in 2017, were dependent on electricity imports. According to the environmental sustainability parameter, Norway and Italy are at the top of the list, while Serbia and Ukraine take 88th and 102nd place out of a total of 125 countries.

When we observe the regulations of the countries, we can conclude that Italy and Norway have the most official legal documents and plans related to direct support to the development of the RES sector. Taking into account that all countries have to achieve the objective of $27 \%$ share of RES by 2020 , it is clear that certain measures need to be implemented in order to encourage investments in RES-using facilities. 
Reljić M., et al: Comparative Analysis of the Use of Renewable Energy Sources in...

\section{References}

Agenda

2030.

https://sustainabledevelopment.un.org/content/documents/21252030\%20Agenda \%20for\%20Sustainable\%20Development\%20web.pdf.

Andrei, J., Mieila, M., Popescu, G., Nica, E., \& Cristina, M. (2016). The Impact and Determinants of Environmental Taxation on Economic Growth Communities in Romania. Energies, 9(11), 902. doi:10.3390/en9110902

Andrei, J.V., Mieila, M., \& Panait, M. (2017). The impact and determinants of the energy paradigm on economic growth in European Union. PLOS ONE, 12(3), 173282. doi:10.1371/journal.pone.0173282

Chang, D., Yeh, L., \& Chen, Y. (2013). The Effects of Economic Development, International Trade, Industrial Structure and Energy Demands on Sustainable Development. Sustainable Development, 22(6), 377-390. doi:10.1002/sd.1555

Devezas, T., LePoire, D., Matias, J.C.O., \& Silva, A.M.P. (2008). Energy scenarios: Toward a new energy paradigm. Futures, 40(1), 1-16. doi:10.1016/j.futures.2007.06.005

Domac, J., Šegon, V., \& Kufrin, K. (2004). Stavovi i informiranost javnosti o obnovljivim izvorima energije i energetskoj e kasnosti. Energija, 53(3); 165-172.

Dusmanescu, D., Andrei, J., \& Subic, J. (2014). Scenario for Implementation of Renewable Energy Sources in Romania. Procedia Economics and Finance, 8, 300-305. doi:10.1016/s2212-5671(14)00094-x

Esso, L.J., \& Keho, Y. (2016). Energy consumption, economic growth and carbon emissions: Cointegration and causality evidence from selected African countries. Energy, 114, 492-497. doi:10.1016/j.energy.2016.08.010

Hornborg, A. (2008). Machine fetishism and the consumer's burden. Anthropology Today, 24(5), 4-5. doi:10.1111/j.1467-8322.2008.00610.x

https://www.iea.org/policiesandmeasures/renewableenergy/?country=Serbia 19.09.2018.

-IRENA. (2016). Renewable Energy Benefits: Measuring The Economics. Abu Dhabi. http://resourceirena.irena.org/gateway/dashboard/?topic=4\&subTopic=16. .

Jorgenson, A.K., Alekseyko, A., \& Giedraitis, V. (2014). Energy consumption, human well-being and economic development in central and eastern European nations: A cautionary tale of sustainability. Energy Policy, 66, 419-427. doi:10.1016/j.enpol.2013.11.020

Mihić, M., Dodevska, Z., Todorović, M., Obradović, V., \& Petrović, D. (2018). Reducing Risks in Energy Innovation Projects: Complexity Theory Perspective. Sustainability, 10(9), 2968. doi:10.3390/su10092968

Mihic, M.M., Petrovic, D.C., \& Vuckovic, A.M. (2014). Comparative Analysis Of Global Trends In Energy Sustainability. Environmental Engineering and Management Journal, 13(4), 947-960. doi:10.30638/eemj.2014.099

Mihić, M., Petrović, D., Obradović, V., \& Todorović, M. (2017). Cost-Benefit analiza. Beograd: Fakultet organizacionih nauka. 221.

Mihic, M., Petrovic, D., Obradovic, V., \& Vuckovic, A. (2015). Project Management Maturity Analysis in the Serbian Energy Sector. Energies, 8(5), 3924-3943. doi:10.3390/en8053924 
Reljić M., et al: Comparative Analysis of the Use of Renewable Energy Sources in...

Pablo-Romero, M.P., Sánchez-Braza, A., \& Pérez, M. (2013). Incentives to promote solar thermal energy in Spain. Renewable and Sustainable Energy Reviews, 22, 198-208. doi:10.1016/j.rser.2013.01.034

Popescu, G.H., Mieila, M., Nica, E., \& Andrei, J.V. (2018). The emergence of the effects and determinants of the energy paradigm changes on European Union economy. Renewable and Sustainable Energy Reviews, 81, 768-774. doi:10.1016/j.rser.2017.08.055

The Energy Progress Report (TRACKING SDG7). https: //trackingsdg7.esmap.org/country/norway.

www.iea.org / https://www.iea.org/topics/renewables/ 19.09.2018.

www.un.org 19.09.2018. 